\title{
IMPACT OF PHYSICAL ACTIVITY ON FATIGUE AND QUALITY OF LIFE OF CANCER PATIENTS
}

\author{
IMPACTO DA ATIVIDADE FISICA NA FADIGA EQUALIDADE DE VIDA DE PACIENTES COM CÂNCER
}

OrIGINAL ARTICLE

IMPACTO DE LA ACTIVIDAD FÍSICA EN LA FATIGA Y CALIDAD DE VIDA DE PACIENTES CON CÁNCER

ARTIGO ORIGINAL

Artículo Original

\begin{abstract}
Antonio Filipe Pereira Caetano' (ID (Physical Education Professional) Diego Augusto Santos Silva² (DD (Physical Education Professional) Priscila Custódio Martins² (ID (Physical Education Professional) José Jean de Oliveira Toscano' (DD (Physical Education Professional)
\end{abstract}

1. Universidade Federal de Alagoas, Institute of Physical Education and Sport, Maceió, AL, Brazil.

2. Universidade Federal de Santa Catarina, Florianópolis, SC, Brazil.

\section{Correspondence:}

Antonio Filipe Pereira Caetano Universidade Federal de Alagoas, Institute of Physical Education and Sport. Av. Prof. Manoel Coelho Neto, 29/203, Jatiúca, Maceió, AL, Brazil. 57036-710.

afpereiracetano@hotmail.com

\begin{abstract}
Introduction: Physical exercise has been considered an important non-pharmacological treatment for reducing tiredness, pain, low self-esteem and increases in body mass in individuals diagnosed with cancer. Objective: To verify the relationship between fatigue, quality of life and levels of physical activity in cancer patients undergoing chemotherapy. Methods: Observational, cross-sectional study. The sample consisted of 85 adult patients undergoing cancer treatment at a university hospital. Physical activity was assessed by the IPAQ, and fatigue and quality of life by the PFS and EORTC QLQ-C30 questionnaires, respectively. Student's $t$ and the Fisher's Exact tests were used to identify differences between active and physically inactive patients for the variables fatigue and quality. Additionally, covariance analysis (ANCOVA) was used, in which simple (outcome and exposure) and adjusted models (age, time of diagnosis and type of cancer) were tested. Results: The study included 85 cancer patients, with a mean of 51.78 years of age ( \pm 11.72$)$. Most were female and not physically active. Patients classified as physically inactive had higher scores for "total fatigue" ( $p=0.01)$, "behavioral" ( $p=0.01)$, "affective" ( $p=0.02)$ and psychological/ sensory fatigue ( $(p=0.04)$, compared to the physically active patients $(p=0.01)$. Patients classified as physically not very active presented poorer quality of life in the dimensions: "Overall" quality of life ( $p=0.05)$ and "functional" $(p=0.04)$, "appetite" $(p=0.02)$, "insomnia" $(p=0.02)$, "diarrhea" $(p=0.04)$, "fatigue" $(p=0.01)$, "pain" $(p=0.01)$ and "nausea" $(p=0.03)$, when compared to the physically active patients in both analyses; simple and adjusted. Conclusion: The practice of physical activity during treatment can be a determining factor for increasing quality of life and reducing fatigue in cancer patients, minimizing the adverse effects of chemotherapy. Level of evidence ll; retrospective study.
\end{abstract}

Keywords: Motor activity; Fatigue; Quality of Life; Neoplasms.

\section{RESUMO}

Introdução: O exercício físico tem sido considerado um importante tratamento não farmacológico para diminuir a sensação de cansaço, as dores, a baixa autoestima e o aumento da massa corporal em indivíduos com diagnóstico de câncer. Objetivo: Verificar a relação entrefadiga, qualidade de vida eníveis de atividade física em pacientes oncológicos submetidos à quimioterapia. Métodos: Estudo observacional, transversal. A amostra foi composta por 85 pacientes adultos em tratamento oncológico em hospital universitário. A atividade fisica foi avaliada pelo IPAQ, a fadiga e a qualidade de vida, pelos questionários PFS e EORTC QLQ-C30, respectivamente. Foram empregados os testes t de Student e Exato de Fisher para identificar diferenças entre os pacientes fisicamente ativos e pouco ativos para as variáveis de fadiga e qualidade de vida. Adicionalmente, foi empregada a análise de covariância (ANCOVA) em que foram testados modelos simples (desfecho e exposição) e ajustados (idade, tempo de diagnóstico e tipo de câncer). Resultados: Participaram do estudo 85 pacientes com câncer emédia de 51,78 anos de idade ( $\pm 11,72)$. A maioria era do sexo feminino e pouco ativa fisicamente. Pacientes classificados como fisicamente pouco ativos apresentaram maiores escores de "fadiga total" ( $p=0,01)$, "comportamental" ( $p=0,01)$, "afetiva" $(p=0,02)$ e fadiga psicológica/sensorial ( $p=0,04)$, em comparação com pacientes fisicamente ativos $(p=0,01)$. Os pacientes classificados como fisicamente pouco ativos tinham pior qualidade de vida nas dimensões: qualidade de vida "geral" ( $p=0,05)$ e "funcional" $(p=0,04)$, "apetite" $(p=0,02)$, "insônia" $(p=0,02)$, "diarreia" $(p=0,04)$, "fadiga" $(p=0,01)$, "dor" $(p=0,01)$ e "náuseas" $(p=0,03)$ quando comparados com os pacientes fisicamente ativos, em ambas as análises, simples e ajustada. Conclusão: A prática da atividade física durante o tratamento pode ser um fator determinante para aumentar a qualidade de vida e reduzir a fadiga em pacientes com câncer, minimizando os efeitos adversos da quimioterapia. Nível de Evidência ll; Estudo retrospectivo.

Descritores: Atividade motora; Fadiga; Qualidade de vida; Neoplasias.

\section{RESUMEN}

Introducción: El ejercicio físico ha sido considerado un importante tratamiento no farmacológico para disminuir la sensación de cansancio, los dolores, la baja autoestima y el aumento de la masa corporal en individuos con diagnóstico de cáncer. Objetivo: Verificar la relación entre fatiga, calidad de vida y niveles de actividad física en pacientes oncológicos sometidos a quimioterapia. Métodos: Estudio observacional, transversal. La muestra fue compuesta por 85 pacientes adultos en tratamiento oncológico en hospital universitario. La actividad física fue evaluada a través de IPAQ, la fatiga y la calidad de vida, por los cuestionarios PFS y EORTCQLQ-C30, respectivamente. Fueron empleados los tests t de Studenty Exacto de Fisher para identificar diferencias entre pacientes fisicamente activos y poco activos para las variables de fatiga y calidad de vida. Adicionalmente, fue empleado el análisis de covariancia (ANCOVA) en el que fueron testeados modelos simples (resultado y exposición) y ajustados (edad, tiempo de diagnóstico y tipo de cáncer). Resultados: Participaron en el estudio 85 pacientes con 
cáncery promedio de 51,78 años de edad ( \pm 11,72). La mayoría era del sexo femenino y poco activa físicamente. Los pacientes clasificados como físicamente poco activos presentaron mayor puntuación de "fatiga total" ( $p=0,01$ ), "comportamental" $(p=0,01)$, "afectiva" ( $p=0,02)$ y fatiga psicológica/sensorial ( $p=0,04)$, en comparación con pacientes físicamente activos $(p=0,01)$. Los pacientes clasificados como físicamente poco activos tenían peor calidad de vida en las dimensiones: calidad de vida "general" $(p=0,05)$ y "funcional" ( $p=0,04)$, "apetito" $(p=0,02)$, "insomnio" $(p=0,02)$, "diarrea" $(p=0,04)$, "fatiga" $(p=0,01)$, "dolor" $(p=0,01)$ y "náuseas" ( $p=0,03)$, cuando comparados con los pacientes físicamente activos en ambos análisis, simples y ajustados. Conclusión: La práctica de actividad física durante el tratamiento puede ser un factor determinante para aumentar la calidad de vida y reducir la fatiga en pacientes con cáncer, minimizando los efectos adversos de la quimioterapia.

Nivel de Evidencia ll; Estudio retrospectivo.

Descriptores: Actividad motora; Fatiga; Calidad de Vida; Neoplasias.

\section{INTRODUCTION}

Cancer is considered the first or second leading cause of premature death in almost 100 countries worldwide, including Brazil, where 600,000 new cases are estimated per year. ${ }^{1}$ In 2017, the World Health Assembly passed a resolution on cancer prevention through an integrated approach, directing governments to accelerate actions to reduce mortality. ${ }^{2}$

According to the Pan American Health Organization (PAHO), about one-third of cancer deaths are due to the five leading behavioral risks, including physical inactivity. ${ }^{3}$ The conventional therapeutic approach involves surgery, chemotherapy, radiation therapy, and hormone therapy, which may cause several biological and behavioral changes, such as the reduction in physical activity levels. ${ }^{4}$

The low daily energy expenditure and the effects of treatment increase fatigue levels (in any type of neoplasms), which are reported by up to $91 \%$ of patients, and may last for up to ten years. ${ }^{5}$ Professionals from various fields indicate physical exercises as an important non-pharmacological treatment for reducing tiredness, pain, low self-esteem, and increased body mass resulting from the fatigue. ${ }^{6}$

The treatments for cancerous tumors activate pro-inflammatory cytokines, causing exhaustion and other disruptive side effects, such as pain, nausea, vomiting, anxiety, depression, and low self-esteem, besides influencing social and emotional aspects, ${ }^{7}$ decreasing thus the quality of life of these patients. According to the literature, practicing physical activity may lessen the severity of these issues, besides providing greater incentive and adherence to physical exercise programs. ${ }^{8}$

Given the favorable evidence of the positive impact of physical exercises on the physical and mental state of patients receiving cancer treatment ${ }^{9}$, university hospitals are promising institutions to investigate fatigue levels and quality of life of this subgroup, due to their multidisciplinary features, through an integrated approach with other university courses linked to the hospital, such as Physical Education.

The main purpose of this study was to verify the association between exhaustion, quality of life, and physical activity levels in cancer patients undergoing chemotherapy at a University Hospital of a Federal Public University.

\section{MATERIALS AND METHODS \\ Type of study}

This is a cross-sectional, observational, and analytical study.

\section{Population and Sample}

The population consisted of adult individuals receiving cancer treatment at the High-Complexity Cancer Care Center (CACON) of the Hospital Universitário Prof. Alberto Antunes (HUPAA), in the city of Maceió, Alagoas, Brazil.

According to CACON-HUPAA records, during the first half of 2018, the department of chemotherapy treated, on average, 256 cancer per month. We used information from the study conducted by Kummer et al. ${ }^{10}$, based on correlation coefficients of investigated variables, to estimate the required sample size. Considering an 80\% power ( $\beta$ ) and a $5 \%$ alpha, a sample size of 85 patients was reached.

Inclusion criteria were: presenting clinical diagnosis of malignant neoplasia, in any location, recurrent or not; having received at least two chemotherapy sessions, regardless of any other treatment associated with chemotherapy. Patients who had some clinical condition that could interfere with the practice of physical activity were excluded from the study.

\section{Instruments}

We selected sociodemographic and clinical variables from previous studies that addressed the same topic as ours. ${ }^{11-12}$

Quality of life was assessed by applying the European Organisation for Research and Treatment of Cancer Quality of Life Questionnaire C30 (EORTC QLQ-C30), specific for cancer patients, and validated for the Portuguese language. ${ }^{13}$ The questionnaire contains 30 questions divided into three scales: global health, functional, and symptoms. Scores range from 0 to 100 and are calculated separately for each scale. In the global and functional health scales, the higher the score, the better the quality of life. Conversely, for the symptom scale, the higher the score, the worse the quality of life.

Fatigue was investigated with the Piper Fatigue Scale (PFS), applied in patients after cancer diagnosis and validated for the Brazilian population. ${ }^{14}$ The scale contains 22 questions divided into three dimensions: behavioral, affective, and cognitive/mood. Each dimension, as well as the total score, receives a score that corresponds to each item mean score, ranging from zero to ten; the closer to 10, the greater the fatigue.

Physical activity was assessed using a short version of the International Physical Activity Questionnaire (IPAQ), validated for Brazil. ${ }^{15}$ The questionnaire contains six questions that analyze the amount of time (at least 10 continuous minutes) spent by the individual with walking and moderate/vigorous physical activity in the last week. Individuals who accumulated 150 minutes or more moderate to vigorous physical activity during the week were considered physically active.

The same researcher applied all questionnaires in the form of an interview to include illiterate patients. All patients were interviewed in the waiting room for chemotherapy before the beginning of the usual session. This study was approved by the Human Research Ethics Committee of the Federal University of Alagoas, under opinion no. 3.455.770, and all participants signed the informed consent form.

\section{Statistical analysis}

First, descriptive data analysis (median and interquartile interval) was carried out, and missing data were excluded. Kurtosis and asymmetry were used to verify data normality (interval between -2 and +2 ), and histogram analysis to test normal distribution. We also used the Fisher's Exact test and Student's t-test to identify differences between physically 
active and inactive patients regarding fatigue and quality of life, and the Analysis of covariance (ANCOVA) to test simple (outcome and exposure) and adjusted models (age, diagnosis time, and cancer type).

Then, simple and multiple linear regression analysis was performed to estimate the regression coefficients ( $\beta$ ), 95\% confidence interval (95\% $\mathrm{Cl}$ ), and coefficient of determination $\left(\mathrm{R}^{2}\right)$ for each model analyzed. For this analysis, the outcomes were each fatigue indicator and quality of life domain; that is, a simple and multiple model was constructed for each of these variables. Exposure was the physical activity level, where "physically active" was deemed as the reference and coefficients were estimated for the category "physically inactive". All analyses were made using the Statistical Package for the Social Scienses (IBM SPSS Statistics, Chicago, United States) software, version 22.0, with significance level set at 5\%.

\section{RESULTS}

The study included 85 cancer patients with mean age of 51.78 years ( \pm 11.72 ). Most were female and physically inactive. Among them, $55.3 \%$ were married, $8.2 \%$ completed higher education, and $38.8 \%$ presented comorbidity. Over $40 \%$ of the sample had been diagnosed with cancer more than three years ago, and the most frequent cancer was breast cancer (Table 1).

The analysis adjusted for age, cancer type, and time since diagnosis found patients classified as physically inactive those who had higher scores of "total fatigue" $(p=0.01)$, "behavioral" $(p=0.01)$, "affective" $(p=0.02)$ and "cognitive/mood fatigue" ( $p=0.04)$ than physically active patients $(p=0.01)$ (Table 2).

The analysis adjusted for age, cancer type, and time since diagnosis found patients classified as poorly active to reach lower scores on the "global" ( $p=0.05$ ) and "functional" ( $p=0.04$ ) quality of life scales than physically active patients, indicating that poorly active patients have a worse quality of life. In the scales "appetite" $(p=0.02)$, "insomnia" $(p=0.02)$, "diarrhea" $(p=0.04)$, "fatigue" $(p=0.01)$, "pain" $(p=0.01)$, and "nausea" $(p=0.03)$, physically inactive patients reached higher scores than those physically active in both simple and adjusted analyses, indicating a worse quality of life (Table 3).

Table 1. Sample characterization according to the regular practice of physical activity.

\begin{tabular}{|c|c|c|c|c|}
\hline & Total $(n=85)$ & \begin{tabular}{|c|} 
Physically \\
active $(n=21)$
\end{tabular} & \begin{tabular}{|c|}
$\begin{array}{c}\text { Poorly active } \\
(n=64)\end{array}$ \\
\end{tabular} & p-value \\
\hline Chronological age (mean \pm sd) & $51.7 \pm 11.7$ & $50.6 \pm 10.8$ & $52.1 \pm 12.0$ & 0.601 \\
\hline Gender $(n, \%)$ & & & & 0.847 \\
\hline Female & $70(64.8)$ & $17(24.3)$ & $53(75.7)$ & \\
\hline Male & $15(13.9)$ & $04(26.7)$ & $11(73.3)$ & \\
\hline \multicolumn{5}{|l|}{ Marital status (n, \%) } \\
\hline Single & $25(29.4)$ & $08(32.0)$ & $17(68.0)$ & 0.392 \\
\hline Married & $47(55.3)$ & $09(19.1)$ & $38(80.9)$ & \\
\hline Divorced/Widowed & $13(15.3)$ & $04(30.8)$ & $09(69.2)$ & \\
\hline \multicolumn{5}{|l|}{ Education level $(n, \%)$} \\
\hline Illiterate & $11(12.9)$ & $01(9.1)$ & $10(90.9)$ & 0.088 \\
\hline Elementary school & $44(51.8)$ & $08(18.2)$ & $36(81.8)$ & \\
\hline High school & $23(27.1)$ & 09 (39.1) & $14(60.9)$ & \\
\hline Higher education & $07(8.2)$ & $03(42.9)$ & $04(57.1)$ & \\
\hline \multicolumn{5}{|l|}{ Comorbidities ( $n, \%)$} \\
\hline Yes & $33(38.8)$ & $11(33.3)$ & $22(66.7)$ & 0.142 \\
\hline No & $52(61.2)$ & $10(19.2)$ & $42(80.8)$ & \\
\hline \multicolumn{5}{|l|}{$\begin{array}{c}\text { Time since cancer } \\
\text { diagnosis }(n, \%)\end{array}$} \\
\hline$\leq 1$ year & $23(27.1)$ & $07(30.4)$ & $16(69.6)$ & 0.589 \\
\hline $1-2$ years & $23(27.1)$ & $04(17.4)$ & $19(82.6)$ & \\
\hline $3-4$ years & $17(20.0)$ & $03(17.6)$ & $14(82.4)$ & \\
\hline$>4$ years & $22(25.8)$ & $07(31.8)$ & $15(68.2)$ & \\
\hline Cancer type (n, \%) & & & & 0.067 \\
\hline Breast cancer & $43(39.8)$ & $12(27.9)$ & $31(72.1)$ & \\
\hline Endometrial-ovarian cancer & $09(8.3)$ & $00(0.0)$ & $09(100.0)$ & \\
\hline Colon cancer & $07(6.5)$ & $03(42.9)$ & $04(57.1)$ & \\
\hline Lung Cancer & $04(3.7)$ & $01(25.0)$ & $03(75.0)$ & \\
\hline Leukemia & $05(4.6)$ & $03(60.0)$ & $02(40.0)$ & \\
\hline Other & $17(15.7)$ & $02(11.8)$ & $15(88.2)$ & \\
\hline
\end{tabular}

Table 2. Comparison of fatigue indicators among physically active and poorly active cancer patients $(\mathrm{n}=85)$.

\begin{tabular}{|c|c|c|c|c|}
\hline \multicolumn{2}{|c|}{ Physically active $(n=21)$} & \multicolumn{3}{|c|}{ Poorly active $(n=64)$} \\
\hline \multicolumn{5}{|c|}{ Total } \\
\hline \multicolumn{2}{|c|}{$M\left(\right.$ SEE $\left.^{* *}\right)$} & M (SEE) & $p$ & $\mathrm{R}^{2}$ \\
\hline Simple & $2.30(0.73)$ & $3.89(0.42)$ & 0.06 & 0.02 \\
\hline Adjusted & $2.10(0.65)$ & $3.96(0.37)$ & $0.01^{*}$ & 0.33 \\
\hline \multicolumn{5}{|c|}{ Behavioral } \\
\hline Simple & $1.98(0.66)$ & $3.35(0.37)$ & 0.07 & 0.02 \\
\hline Adjusted & $1.79(0.58)$ & $3.41(0.33)$ & $0.01^{*}$ & 0.31 \\
\hline \multicolumn{5}{|c|}{ Affective } \\
\hline Simple & $3.00(0.95)$ & $4.95(0.54)$ & 0.08 & 0.02 \\
\hline Adjusted & $2.77(0.87)$ & $5.02(0.50)$ & $0.02^{*}$ & 0.30 \\
\hline \multicolumn{5}{|c|}{ Cognitive/Mood } \\
\hline Simple & $2.04(0.66)$ & $3.23(0.38)$ & 0.12 & 0.01 \\
\hline Adjusted & $1.86(0.60)$ & $3.29(0.34)$ & $0.04^{*}$ & 0.30 \\
\hline
\end{tabular}

Table 3. Comparison of quality of life scales among physically active and poorly active cancer patients $(n=85)$.

\begin{tabular}{|c|c|c|c|c|}
\hline \multicolumn{2}{|c|}{ Physically active $(n=21)$} & \multicolumn{3}{|c|}{ Poorly active $(n=64)$} \\
\hline \multicolumn{5}{|c|}{ Global } \\
\hline & M (SEE) & M (SEE) & $\mathrm{P}$ & $\mathrm{R}^{2}$ \\
\hline Simple & $66.76(5.19)$ & $55.15(2.97)$ & 0.05 & 0.03 \\
\hline Adjusted & $66.80(5.18)$ & $55.14(2.96)$ & 0.05 & 0.17 \\
\hline \multicolumn{5}{|c|}{ Functional } \\
\hline Simple & $71.47(4.60)$ & $62.07(2.63)$ & 0.08 & 0.02 \\
\hline Adjusted & $72.15(4.47)$ & $61.85(2.55)$ & 0.04 & 0.08 \\
\hline \multicolumn{5}{|c|}{ Physical } \\
\hline Simple & $5.23(2.82)$ & $11.09(1.62)$ & 0.07 & 0.02 \\
\hline Adjusted & $5.14(2.85)$ & $11.12(1.63)$ & 0.07 & 0.01 \\
\hline \multicolumn{5}{|c|}{ Role } \\
\hline Simple & $11.09(5.15)$ & $15.95(2.95)$ & 0.41 & 0.01 \\
\hline Adjusted & $10.87(5.17)$ & $16.02(2.96)$ & 0.39 & 0.02 \\
\hline \multicolumn{5}{|c|}{ Cognitive } \\
\hline Simple & $10.19(3.85)$ & $11.29(2.20)$ & 0.80 & 0.01 \\
\hline Adjusted & $10.06(3.90)$ & $11.33(2.23)$ & 0.77 & 0.03 \\
\hline \multicolumn{5}{|c|}{ Social } \\
\hline Simple & $10.76(2.67)$ & $6.37(5.37)$ & 0.23 & 0.01 \\
\hline Adjusted & $16.70(4.64)$ & $10.90(2.65)$ & 0.28 & 0.02 \\
\hline \multicolumn{5}{|c|}{ Emotional } \\
\hline Simple & $23.85(5.51)$ & $23.21(3.40)$ & 0.92 & 0.01 \\
\hline Adjusted & $22.66(5.65)$ & $23.61(3.23)$ & 0.88 & 0.08 \\
\hline \multicolumn{5}{|c|}{ Dyspnea } \\
\hline Simple & $11.04(6.89)$ & $24.32(3.95)$ & 0.09 & 0.02 \\
\hline Adjusted & $10,10(6.78)$ & $24.63(3.88)$ & 0.06 & 0.05 \\
\hline \multicolumn{5}{|c|}{ Appetite } \\
\hline Simple & $14.23(7.80)$ & $34.70(4.47)$ & 0.02 & 0.04 \\
\hline Adjusted & $14.20(7.84)$ & $34.71(4.48)$ & 0.02 & 0.04 \\
\hline \multicolumn{5}{|c|}{ Insomnia } \\
\hline Simple & $25.28(9.42)$ & $58.75(5.39)$ & $<0.01$ & 0.09 \\
\hline Adjusted & $24.10(9.24)$ & $59.13(5.28)$ & 0.02 & 0.23 \\
\hline \multicolumn{5}{|c|}{ Constipation } \\
\hline Simple & $17.33(6.70)$ & $17.07(3.84)$ & 0.97 & 0.01 \\
\hline Adjusted & $17.28(6.74)$ & $17.09(3.88)$ & 0.98 & 0.03 \\
\hline \multicolumn{5}{|c|}{ Diarrhea } \\
\hline Simple & $4.71(3.96)$ & $21.28(3.96)$ & 0.04 & 0.03 \\
\hline Adjusted & $4.62(6.98)$ & $21.31(3.99)$ & 0.04 & 0.02 \\
\hline \multicolumn{5}{|c|}{ Financial } \\
\hline Simple & $39.57(9.07)$ & $41.53(5.19)$ & 0.85 & 0.01 \\
\hline Adjusted & 38.05 (8.79) & $42.03(5.02)$ & 0.69 & 0.05 \\
\hline \multicolumn{5}{|c|}{ Fatigue } \\
\hline Simple & $22.04(8.73)$ & $46.71(5.00)$ & 0.01 & 0.05 \\
\hline Adjusted & $21.63(8.79)$ & $46.85(5.03)$ & 0.01 & 0.11 \\
\hline \multicolumn{5}{|c|}{ Pain } \\
\hline Simple & $33.09(8.40)$ & $53.93(4.81)$ & 0.03 & 0.04 \\
\hline Adjusted & $31.60(8.01)$ & $54.42(4.58)$ & 0.01 & 0.25 \\
\hline \multicolumn{5}{|c|}{ Nausea } \\
\hline Simple & $17.38(8.42)$ & $38.39(4.82)$ & 0.03 & 0.04 \\
\hline Adjusted & $16.97(8.51)$ & $38.52(4.87)$ & 0.03 & 0.05 \\
\hline
\end{tabular}

M: Mean; SEE: standard error of the estimate; $R^{2}$ : coefficient of determination. Simple model: outcome and exposition; Adjusted model: age, cancer type, and time since diagnosis. 


\section{DISCUSSION}

For being one of the most common side effects during treatment, identifying and treating cancer-related fatigue is fundamental for the social reintegration of cancer patients. ${ }^{16}$ By investigating the association between this fatigue and physical activity levels throughout a multidisciplinary oncologic rehabilitation program of patients under treatment, we verified a substantial reduction in cancer-related exhaustion with the increase in energy expenditure, regardless of the treatment. ${ }^{6}$

Fatigue alone may preclude patients from becoming (more) active. Physical exercises do not increase treatment-related exhaustion, but exercise programs should be careful in incorporating high-intensity activities to not interfere with patients' adherence to treatment. ${ }^{17}$ Evidence indicates that moderate-intensity aerobic activity is more effective in combating this issue, besides improving treatment adherence. ${ }^{18-19}$

Cancer-related exhaustion is a multidimensional indicator: being physically active may bring positive effects in all dimensions of life. (Table 2) The impact of physical activity in these aspects may be explained by an improvement in fitness, especially cardiorespiratory strength and resistance, and indirectly by its effects on mood or immune function. ${ }^{20}$

The National Comprehensive Cancer Network (NCCN) Clinical Practice Guidelines in Oncology recommends physical activity as an important non-pharmacological strategy for managing fatigue, being considered a standard to be adopted in the therapy during and after treatment. ${ }^{21}$

Instruments assessing health-related quality of life include, among their investigated dimensions, functional aspects and a global quality of life scale. ${ }^{22}$ In the specific case of cancer patients, this concern is justified by the weaknesses caused by radiotherapy or chemotherapy cytotoxicity, reducing cardiorespiratory capacity, muscle strength and mass, and physical activity levels, and affecting activities of daily life. ${ }^{23}$

Considering that demographic and clinical data of the population with cancer may interfere in the differences among physically active groups, ${ }^{24}$ we found a significant contrast in the quality of life scores regarding general and functional status between physically active and poorly active individuals after adjusting sample data for cancer type and age.

Another essential characteristic of our sample was that all patients were in active treatment, which may imply greater deterioration of health-related quality of life components. The literature on systematic reviews and meta-analyses, with over 4,000 cancer patients, found that physical exercise significantly increases global and functional quality of life scales, specially regarding functional components, when compared to control groups. ${ }^{25-26}$

The most common side effects of chemotherapy are nausea, vomiting, pain, and fatigue, affecting not only patients' physical aspects, but also their emotional and cognitive aspects ${ }^{27}$. Practicing exercises may mitigate the severity of these side effects, resulting in a positive impact on the quality of life of cancer patients. ${ }^{24}$ In our sample, physically active individuals reached better scores than poorly active individuals in several indicators of the investigated symptoms (Table 3), improving sleep, pain, and fatigue, and corroborating findings reported in the literature. ${ }^{28}$

In the USA alone, the number of cancer survivors is expected to increase from 14 million in 2014 to 19 million in $2024^{26}$, arising the need for developing strategies to relieve the side effects in the subgroup under treatment. The literature indicates that moderate-intensity exercise programs with mixed components (resistance and aerobic) reduce fatigue and improve quality of life scores. ${ }^{29}$

A study conducted in a Brazilian northeastern city with women with breast cancer in various stages and treatments found a positive correlation between exercises, exhaustion, and quality of life. The authors concluded that physical activity is an essential behavior to enhance wellbeing in cancer patients. ${ }^{12}$

Regardless of the type of treatment or age, increased levels of daily physical activity were associated with improvements in quality of life and fatigue. ${ }^{14}$ Patients satisfaction with their functionality levels and increased muscle strength and cardiorespiratory resistance were some mechanisms mentioned by the authors, directly interfering in the perceived exhaustion and consequently in quality of life.12, 29

A limitation of our study was its cross-sectional design, as it does not allow us to establish temporality relationships among the investigated variables. Another limitation was the inclusion of different types of cancer, because there is not enough evidence on whether physical activity is a protective factor for all types of cancer. However, we observed differences between the investigated groups, indicating that these limitations did not fully affect the study validity. Moreover, a single researcher collected all data.

As a positive aspect, this study was conducted at a teaching hospital, where developing actions involving physical exercise protocols and/or other strategies focused on this purpose is a real possibility.

\section{CONCLUSIONS}

Physical activity during treatment may be a determining factor for increasing the quality of life and reducing fatigue of cancer patients, minimizing chemotherapy side effects. In this study, we verified that patients who do at least 150 minutes of moderate to vigorous weekly physical activities experienced less fatigue in all dimensions and presented better scores in terms of quality of life.

Health professionals working with cancer patients must necessarily recommend the practice of physical activity from diagnosis to treatment, especially in supervised programs, where patents adherence is higher.

All authors declare no potential conflict of interest related to this article

AUTHORS' CONTRIBUTIONS: Each author made significant individual contributions to this manuscript. AFPC and JJOT: were the main contributors in the writing of the manuscript and performed the data collection at Hospital Universitário Prof. Alberto Antunes. DASS and PCM: evaluated the data from the statistical analysis. All authors performed the bibliographic review and revision of the manuscript, and contributed to the intellectual concept of the study.

\section{REFERENCES}

1. INCA, Ministério da Saúde. Estimativa 2018: incidência de câncer no Brasil//nnstituto Nacional de Câncer José Alencar Gomes da Silva. Coordenação de Prevenção e Vigilância. Rio de Janeiro: INCA; 2017.

2. Bray F, Ferlay J, Soerjomataram I, Siegel RL, Torre AL, Jemal A. Global Cancer Statistics 2018: GLOBOCAN estimates of incidence and mortality worldwide for 36 cancers in 185 countries. CA Cancer J Clin. 2018:68(6):394-424.

3. GBD 2015 Risk Factors Collaborators. Global, regional, and national comparative risk assessment of 79 behavioural, environmental and occupational, and metabolic risks or clusters of risks, 1990-2015 a systematic analysis for the Global Burden of Disease Study 2015. Lancet. 2016;388(10053):1659-724.

4. Seixas RJ, Kessler A, Frison VB. Atividade Física e Qualidade de Vida em Pacientes Oncológicos durante o Período de Tratamento Quimioterápico. Rev Bras Cancerol. 2010;56(3):321-30.
5. Bower JE, Ganz PA, Desmond KA, Bernaards C, Rowland JH, Meyerowitz BE, et al. Fatigue in long-term breast carcinoma survivors: a longitudinal investigation. Cancer. 2006;106(4):751-8.

6. Menezes-Échavez JF, González-Jiménez E, Correa-Bautista JE, Valle JSR, Ramírez-Vélez R. Efectividad del exercicio fisico en la fadiga de pacientes con cáncer durante el tratamento activo: revisión sistemática y metaanálises. Cad Saúde Pública. 2015;31(4):667-81

7. Bezerra KB, Chein MBC, Ferreira PR, Maranhão JKP, Mochel EG, Ribeiro NL, et al. Qualidade e vida de mulheres tratadas de câncer de mama em uma cidade do nordeste do Brasil. Ciênc saúde colet. 2013;18(7):1933-41.

8. Castro Filha JL, Miranda AKP, Martins Júnior FF, Costa HA, Figueiredo KRFV, Oliveira Junior MNS, et al. Influências do Exercício Físico na Qualidade de Vida em Dois Grupos de Pacientes com Câncer de Mama. Rev Bras Ciênc Esporte. 2016;38(2):107-14. 
9. Fairman $C M$, Focht $B C$, Lucas $A R$, Lustberg $M B$. Effects of exercise interventions during different treatments in breast cancer. J Community Support Oncol. 2016;14(5):200-9.

10. Kummer F, Catuogno S, Perseus JM, Bloch W, Baumann FT. Relationship between cancer-related fatigue and physical activity in inpatient cancer rehabilitation. Anticancer Res. 2013;33(8):3415-22.

11. Canário AC, Cabral PU, de Paiva LC, Florencio GL, Spyrides MH, Gonçalves AK. Physical activity, fatigue and quality of life in breast cancer patients. Rev Assoc Med Bras. 2016;62(1):38-44.

12. Boing L, Fretta TB, Vieira MCS, Denig LA, Bergmann A, Guimarães ACA. Physical activity, fatigue and quality of life during a clinical adjuvant treatment of breast cancer: a comparative study. Motri. 2018;14(2-3):59-70.

13. Michels FAS, Latorre MRDO, Maciel MS. Validity, reliability and understanding of the EORTC-C30 and EORTC-BR23, quality of life questionnaires specific for breast cancer. Rev Bras Epidemiol. 2013;16(2):352-63.

14. Mota DDCF, Pimenta CAM, Piper BF. Fatigue in Brazilian cancer patients, caregivers, and nursing students: psychometric validation study of the Piper Fatigue Scale-Revised. Support Care Cancer. 2009;17(6):645-52.

15. Matsudo S, Araújo T, Matsudo V, Andrade D, Andrade E, Oliveira LC, et al. Questionário Internaciona de Atividade Física (IPAQ): Estudo de Validade e Reprodutibilidade no Brasil. Rev Bras Ativ Fís Saúde. 2001;6(2):1-14.

16. Mitchell SA, Beck SL, Hood LE, Moore K, Tanner ER. Putting evidence into practice: Evidence-based interventions for fatigue during and following cancer and its treatment. Clin J Oncol Nurs. 2007;1 1(1):99-113

17. Williams TE, Chalder T, Sharpe M, White PD. Heterogeneity in chronic fatigue syndrome - empirically defined subgroups from the PACE trial. Psychol Med. 2017;47(8):1454-65.

18. Dennett AM, Peiris CL, Shields N, Prendergast LA, Taylor NF. Moderate-intensity exercise reduces fatigue and improves mobility in cancer survivors: a systematic review and meta-regression. $J$ Physiother. 2016;62(2):68-82.

19. Kessels $E$, Husson O, Feltz-Cornelis CM. The effect of exercise on cancer-related fatigue in cancer survivors: a systematic review and meta-analysis. Neuropsychiatric Dis Treat. 2018;14:479-94.
20. Kelley GA, Kelley KS. Exercise and cancer-related fatigue in adults: a systematic review of previous systematic reviews with meta-analyses. BMC Cancer. 2017;17(1):693.

21. NCCN clinical practice guidelines in oncology (NCCN Guidelines): Cancer-related fatigue. 2014. [Acesso em 23 maio 2019]. Disponível em: https://www.nccn.org/professionals/physician_gls/defaultaspx

22. Lopes CF, Queiroga FCG, Fonseca VMB, Ferreira TS, Dourado AM, Lages AL, et al. Conceito e instrumentos de avaliação da qualidade de vida e saúde. Revista Eletrônica Acervo Saúde. 2018;11 Supl:S1076-80

23. Jones LW, Eves ND, Haykowsky M, Freedland SJ, Mackey JR. Exercise intolerance in cancer and the role of exercise therapy to reverse dysfunction. Lancet Oncol. 2009;10(6):598-605.

24. Buffart LM, Kalter J, Sweegers MG, Courneya KS, Newton RU, Aaronson NK, et al. Effects and moderators of exercise on quality of life and physical function in patients with cancer: An individual patient data meta-analysis of 34 RCTs. Cancer Treat Rev. 2017;52:91-104.

25. Mishra SI, Scherer RW, Snyder C, Geigle PM, Berlanstein DR, Topaloglu O. Exercise interventions on health-related quality of life for people with cancer during active treatment. Cochrane Database Syst Rev. 2012;(8):CD008465.

26. Ubago-Guisado E, Gracia-Marco L, Cavero-Redondo I, Martinez-Vizcaino V, Notario-Pacheco B, Pozuelo-Carrascosa DP, et al. Effect of different types of exercise on health-related quality of life during and after cancer treatment: a protocol for a systematic review and network meta-analysis. BMJ Open. 2019;9(11):e031374.

27. Cardoso FMC, Nicolussi AC, Okino L, Sawada NO, Zago MMF. Avaliação da qualidade de vida de pacientes com câncer submetidos à quimioterapia. Rev Esc Enferm USP. 2009;43(3):581-7.

28. Batista RF, Carneiro PFP, Sampaio S, Silva ECS, Silva LF, Silva M. Câncer de mama e qualidade de vida durante o tratamento radioterápico. Ciências Biológicas e da Saúde. 2014;1(3):85-93.

29. Segal R, Zwaal C, Green E, Tomasone JR, Loblaw A, Petrella T. Exercise for people with cancer: a clinical practice guideline. Curr Oncol. 2017;24(1):40-6. 